\title{
Review of the development of China's Eco-industrial Park
} Standard System

\author{
Beijia Huang ${ }^{\mathrm{a}}$, Geng Yong ${ }^{\mathrm{b}}$, Juan Zhao ${ }^{\mathrm{a}}$, Teresa Domenech ${ }^{\mathrm{c}}$, Zhe Liu ${ }^{\mathrm{d}}$, Shun Fung Chiue, Will \\ McDowall $^{c}$, Raimund Bleischwitz ${ }^{c}$, Jingru Liu ${ }^{f}$, Yang Yao $^{f}$ \\ ${ }^{a}$ College of Environment and Architecture, University of Shanghai for Science and Technology, Shanghai, China \\ ${ }^{\mathrm{b}}$ School of Environmental Science and Engineering, Shanghai Jiao Tong University, Shanghai,China \\ ${ }^{c}$ Institute for Sustainable Resources, University College London, London, UK \\ ${ }^{\mathrm{d}}$ School for Resource and Environmental Studies, Dalhousie University, Halifax, Canada \\ ${ }^{\mathrm{e}}$ Gokongwei College of Engineering, De La Salle University, Manila, Philippines \\ ${ }^{\mathrm{f}}$ Chinese Research Academy of Environmental Sciences, Beijing, China
}

Abstract: Eco-industrial Parks (EIP) have become a central element in China's industrial strategy to combine industrial development while minimizing environmental impacts and improving resource efficiency. A national standard system has been developed as a main tool for assessing EIPs. This paper provides a review of the development of China's EIP standard system. The focus of the analysis is the new national demonstration EIP standard (HJ/T274-2015), including a review of calculation methods for some key indicators. The analysis also provides a comparison with previous standards to identify the main changes and improvements in the assessment of EIPs. Comparison findings illustrate that the new standard provides a more consistent indicator system by providing a consolidated standard system, and offering more comprehensive and quantitative indicators. Moreover, the new standard aims to better manage environmental issues by supplementing more comprehensive environmental indicators. The standard also strengthens the emphasis of the industrial symbiosis dimension in the evaluation of EIPs. By offering optional indicators and giving distinct targets based on contextual conditions for a number of indicators, the flexibility and rationality of the EIP assessments are also enhanced. Although many positive changes have been identified, there are still some shortcomings exist in the new EIP standard. The paper proposes a number of recommendations based on analyzing shortcomings, for instance further improving of the industrial symbiosis indicators, offering social benefit evaluation indicators, and strengthening the reduction action evaluation. China's experience of setting EIP standards and indicators may provide lessons for other countries' attempts to develop industrial estate indicators. In order to observe and effectively promote industrial estates at the global range, 
1 several remaining research questions that need further exploration are put forward in this

2 study.

3 Keywords: Eco-industrial Park; Industrial Symbiosis; Standard system; China

\section{1. Introduction}

With the aim of responding to environmental pollution and global warming, many countries are seeking innovative ways to relieve these problems. Establishing Eco-industrial Parks (EIPs) is considered as one effective way for coordinating environmental pollution and economic development (Lai, 2013; UNEP, 1997; Zhang et al., 2010; Song et al., 2015). Though being a policy-concept which is infused with different meanings depending on political, socio-economic and cultural context (Boons et al., 2017), EIP is usually proposed as a community of manufacturing and service businesses seeking enhanced environmental, economic, and social performance through collaboration in managing environmental and resource issues (Lowe, 1997; Valenzuela-Venegas et al, 2016).

Practically, a precursor to EIP is the regional industrial symbiosis ${ }^{1}$ at Kalundborg in Denmark, uncovered in 1990 (Ehrenfeld and Gertler, 1997; Chertow, 2000). Other eco-innovation park cases were also initiated and investigated, such as in the US (Chertow, 2000), Canada (Cote and Cohen-Rosenthal, 1998; Fleig, 2000), Korea (Kim and Powell, 2008; Park et al., 2008; Park et al., 2016), Japan (Van Berkel et al., 2009; Geng et al., 2010), European countries (Massard et al., 2014) and Australia (Roberts, 2004; Van Berkel, 2007; Van Beers et al., 2007). China began to facilitate the EIP strategy in early 2000s and actively promoted it with the enactment of both cleaner production promotion law and circular economy promotion law (Geng et al., 2003, 2009, 2013, 2016; Chiu, 2001; Fang et al., 2007, Shi et al., 2012; McDowall et al. 2017). The first reported EIP case in China is the Guitang sugar-making complex approved by the State Environmental Protection

\footnotetext{
${ }^{1}$ Industrial symbiosis is a subset of industrial ecology, which is usually happened in EIPs. Industrial symbiosis engages traditional separate industries in a collective approach to competitive advantage involving physical exchange of materials, energy, water and by-products. The key to industrial symbiosis are collaboration and the synergistic possibilities offered by geographic proximity (Chertow, 2000).
} 
1 Administration (SEPA) ${ }^{2}$ (Zhu and Cote, 2004; Zhu et al., 2007). China developed 2 large amount of EIP networks since then.

Although EIP can be developed and promoted in different forms (Baas, 2008), setting of standards and guidelines is found helpful for promoting EIP development in China (Shi et al., 2012). Several regions also designed their own EIP criteria, including Port of Cape Charles in the US, Virginia in the US, Thailand, and the

7 Eco-star criteria in Devens, Massachusetts (Cote and Liu, 2016). Yet only China 8 designed a national EIP standard that is applied in large number of parks, and there is no internationally accepted standard for EIP. Several studies discussed about the EIP evaluation standard system in China. Geng et al. (2008) argued that some of the criteria in EIP standard released by SEPA in 2006 are vague and difficult to evaluate. Meanwhile, the standard is criticized as having not considered the principles of eco-industrial development and local realities (Geng et al., 2009). Yu et al. (2014) and Liu et al. (2007) reviewed the EIP performance according to the Chinese EIP standards, and found indicators such as reuse rate of reclaimed water and recycling rate of solid waste are usually challenging for industrial parks to execute.

As mentioned, China has become a major player in EIP experimentation in the last decade, and uses the EIP standardas a main management tool to promote the EIP development. Reflection on the experience indicates that the development of practical quantitative assessment indicators for EIPs has been a crucial factor for the ongoing success of China's national demonstration EIP program (Shi et al., 2012). The performance of environmental pollutant emission and energy consumption intensity in certified EIPs has been shown to be much better than the average level of ordinary industrial parks (Tian et al., 2014). In this sense, a review of the EIP standard system is crucial in understanding how it has evolved over time adapting to both criticism from academia and needs from business. EIP standards in China have already experienced several rounds of revision since the first standards were established in 2006. In 2015, MEP (Ministry of Environmental Protection) released the new standard for national demonstration EIP (HJ/T274-2015) to replace the previous standards. Our literature review reveals that although several articles discussed the

31 Chinese EIP standard system released in 2006 and 2009, no research has yet been

${ }^{2}$ State Environmental Protection Administration (SEPA) changed to Ministry of Environmental Protection (MEP) in 2008. 
1 undertaken to investigate the 2015 standard and assess progress. In order to fill this

2 research gap, this paper will carry out an analysis of the newly released EIP standard.

3 We will try to identify the primary changes and key improvements of the new version

4 of EIP standard system. Furthermore, we will try to explore what are the

5 shortcomings still existing in the new standard.

\section{2. Research framework and methodology}

\section{$7 \quad 2.1$ Research framework}

This study will first give a review of Chinese EIP standards development. The

9 newest 2015 version of standard is illustrated in the manuscript, while the 2006 and

102009 versions are presented in our supplement material. Meanwhile, the enforcement 11 and management mechanisms of EIPs in China are described. As the next step, the 12 main changes among the series of EIP standards will be identified, and reasons of the modifications are discussed. Furthermore, shortcomings of the existing standard and outlook of EIP standard development in China are analyzed.

\subsection{Methodology}

Several approaches are conducted to collect materials and information in this 17 study, including literature and report review, stakeholder interview and informal meetings. (1) The review of the EIP standard development was based on the released EIP standard documents. (2) Reasons of the several rounds' modifications were collected by interview and informal meetings with EIP standard designers from China

21 Environmental Science Research Institute. (3) Critical analysis including the 22 shortcomings of the current EIP standard and outlook of the EIP standard 23 development is conduced based on interviews and informal meetings with EIP 24 standard designers, EIP administrative office members and resarchers of the EIP 25 fields. 


\section{3. China's EIP development}

\section{$2 \quad 3.1$ EIP and standards development}

There are many types of industrial parks in China. In fact, it needs to be recognized that a significant share of China's manufacturing is being managed through those parks, much larger than e.g. in OECD countries (Mathews and Tan 2016). In order to better manage these industrial parks, SEPA categorized these industrial parks into three groups, namely the sector-integrated group, the venous ${ }^{3}$

8 group and the sector-specific group (EPA, 2007). The sector-integrated group refers to those parks with multiple industrial sectors, especially the development zones, which are the main form of Chinese industrial park. The venous industrial park particularly refers to those resource recovery parks where environmental technology companies and firms making "green products" coexist. The sector-specific group refers to parks with primarily one main sector or correlated sectors (Geng et al., 2009).

Before 2006, the sector-specific EIP accounted for the largest percentage among the three kinds of industrial parks, including steel industry, cement industry and paper industry. In 2006, the award of EIP for Qingdao New World venous industry park 4 indicated that the venous industry become a new type of EIP in China. By the end of 2008, 30 national demonstration EIPs construction plan had been endorsed by MEP,

20 including 20 sector-integrated EIPs, 9 sector-specific EIPs and 1 venous industry EIP.

21 The development of sector-integrated EIP grew rapidly from 2006 to 2009, with even 22 higher expanding rate after 2010 (Yu, 2015). By the end of 2015, there are already 23126 national EIPs demonstration plans being endorsed, including 109 24 sector-integrated EIPs, 14 sector-specific EIPs and 3 venous industry EIPs (see Fig.1).

\footnotetext{
3 The term “venous industry” (静脉产业) is widely used in China and Japan, and refers to resource recovery or secondary material industries. This is by analogy with the circulatory system: arteries carry oxygen-rich blood to the body, while veins return blood that has had its oxygen used up. The term 'venous' thus refers to secondary cycles of materials and energy, while 'arterial' industries are those engaged in primary flows of virgin materials.

${ }^{4}$ Due to environmental illegalty, Qingdao New World venous industry park was punished and removed the title of demonstration EIP in 2016. http://www.zhb.gov.cn/gkml/hbb/bgth/201612/t20161212_368966.htm
} 


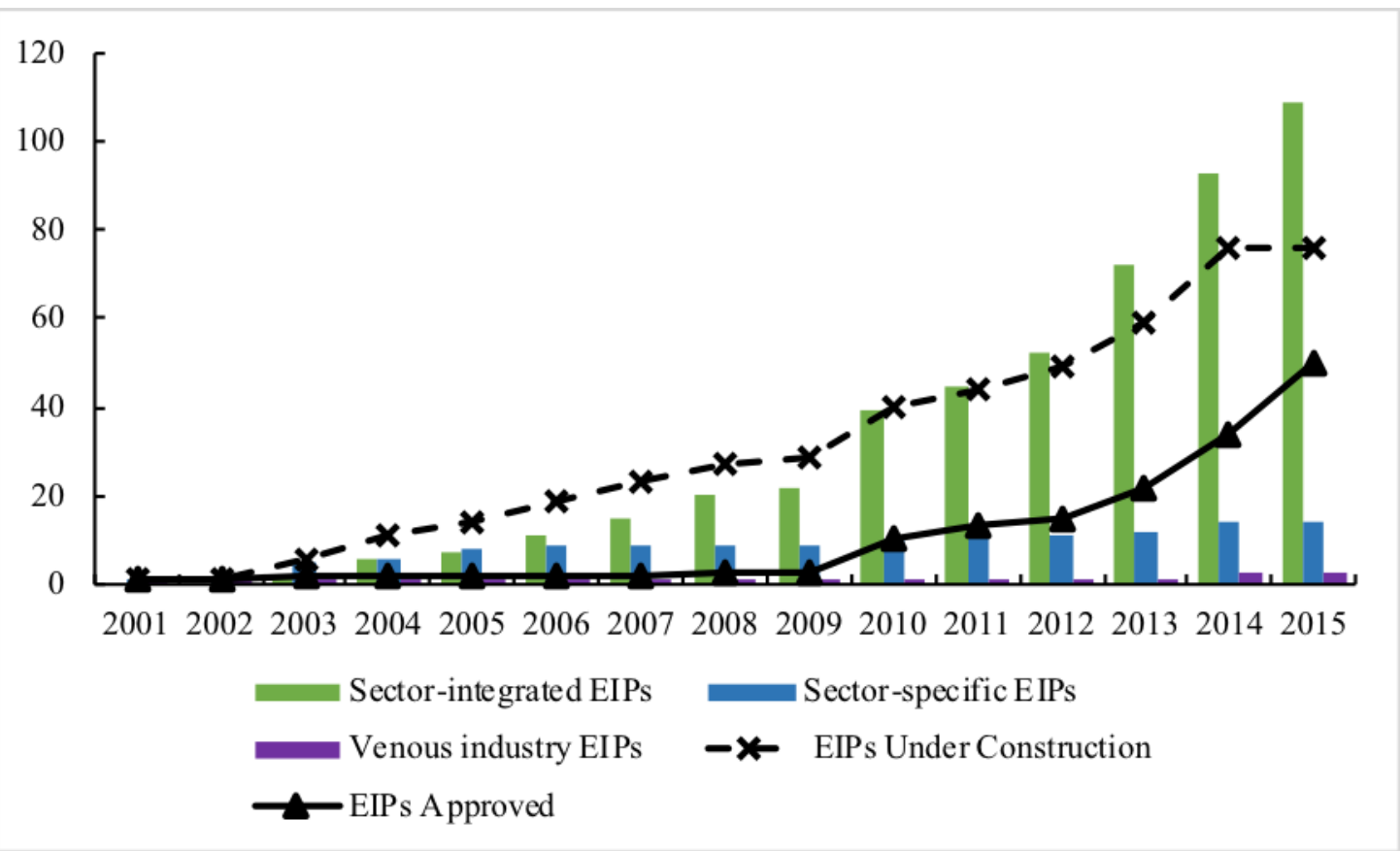

Fig.1 China's EIPs development since 2001 to 2015

Source: Bai et al., 2014; MEP announcement http://kjs.mep.gov.cn/stgysfyq/sp/?COLLCC $=817526580 \&$

Alongside with EIP development, the EIP standards also experienced several rounds of evolution. The development process of standard systems for Chinese EIPs is summarized in Table 1(MEP, 2016).

Table 1 EIP standards in China

\begin{tabular}{|c|l|}
\hline Date & \multicolumn{1}{|c|}{ Document } \\
\hline 2006 & $\begin{array}{l}\text { 1. Tentative Standard for Sector-specific Eco-industrial Parks (HJ/T273-2006) } \\
\text { 2. Tentative Standard for Sector-integrated Eco-industrial Parks (HJ/T274-2006) } \\
\text { 3. Tentative Standard for Venous Industry Based Eco-industrial Parks } \\
\end{array}$ \\
\hline 2009 & Standard for Sector-integrated Eco-industrial Parks(HJ/T274-2009) \\
\hline 2012 & Revised Standard for Sector-integrated Eco-industrial Parks (HJ/T274-2009) \\
\hline 2015 & Standard for National Demonstration Eco-industrial Parks (HJ/T274-2015) \\
\hline
\end{tabular}

12 while those already approved EIPS are required to implement this new standard from 13 January 1, 2019. In order to better understand the new EIP standard (HJ/T274-2015), 14 the whole indicators group are shown in Table 2. The added or modified items by comparing with the previous versions are highlighted. 
Table 2 Evaluation indicators for National Eco-industrial Parks (HJ/T274-2015)

\begin{tabular}{|c|c|c|c|c|c|}
\hline Groups & NO. & Indicators & Units & Standard & Remarks \\
\hline \multirow[t]{4}{*}{$\begin{array}{l}\text { Economic } \\
\text { development }\end{array}$} & 1 & $\begin{array}{l}\text { The proportion of high tech } \\
\text { enterprises output value of } \\
\text { gross industrial output value }\end{array}$ & $\%$ & $\geq \mathbf{3 0}$ & \multirow{4}{*}{$\begin{array}{l}\text { At least } \\
\text { one } \\
\text { indicator } \\
\text { shall reach } \\
\text { the } \\
\text { standard }\end{array}$} \\
\hline & 2 & $\begin{array}{l}\text { Industrial added value per } \\
\text { capita }\end{array}$ & $\begin{array}{l}10^{4} ¥ / \text { Perso } \\
\mathrm{n}\end{array}$ & $\geq 15$ & \\
\hline & 3 & $\begin{array}{l}\text { The average three-year } \\
\text { growth rate of industrial } \\
\text { added value }\end{array}$ & $\%$ & $\geq 15$ & \\
\hline & 4 & $\begin{array}{l}\text { The proportion of } \\
\text { remanufacturing industry } \\
\text { added value of the gross } \\
\text { industrial added value }\end{array}$ & $\%$ & $\geq \mathbf{3 0}$ & \\
\hline \multirow[t]{3}{*}{$\begin{array}{l}\text { Industrial } \\
\text { symbiosis }\end{array}$} & 5 & $\begin{array}{l}\text { The added eco-industrial } \\
\text { chain numbers after enforcing } \\
\text { EIP demonstration program }\end{array}$ & Unit & $\geq 6$ & required \\
\hline & 6 & $\begin{array}{l}\text { Comprehensive utilization rate } \\
\text { of industrial solid waste }\end{array}$ & $\%$ & $\geq 70$ & \multirow{2}{*}{$\begin{array}{l}\text { At least } \\
\text { one } \\
\text { indicator } \\
\text { shall reach } \\
\text { the } \\
\text { standard }\end{array}$} \\
\hline & 7 & $\begin{array}{l}\text { Usage rate of renewable } \\
\text { resources }\end{array}$ & $\%$ & $\geq \mathbf{8 0}$ & \\
\hline \multirow[t]{3}{*}{$\begin{array}{l}\text { Resource } \\
\text { conservation }\end{array}$} & 8 & $\begin{array}{l}\text { Industrial added value per } \\
\text { unit industrial land area }\end{array}$ & $\begin{array}{l}\text { Hundred } \\
\text { million/Sq } \\
\text { uare } \\
\text { kilometers }\end{array}$ & $\geq 9$ & \multirow{2}{*}{$\begin{array}{l}\text { At least } \\
\text { one } \\
\text { indicator } \\
\text { shall reach } \\
\text { the } \\
\text { standard }\end{array}$} \\
\hline & 9 & $\begin{array}{l}\text { The average three-year } \\
\text { annual growth rate of } \\
\text { industrial added value per } \\
\text { unit industrial land area }\end{array}$ & $\%$ & $\geq 6$ & \\
\hline & 10 & $\begin{array}{l}\text { Elastic coefficient of } \\
\text { comprehensive energy } \\
\text { consumption }\end{array}$ & - & $\begin{array}{l}\text {-When annual growth } \\
\text { rate of industrial added } \\
\text { value in the EIP } \\
\text { demonstration period } \\
\text { is }>0 \text { : the value must be } \\
\leqslant 0.6 \text {; } \\
\text {-When annual growth } \\
\text { rate of industrial added } \\
\text { value in the EIP } \\
\text { demonstration period is }\end{array}$ & required \\
\hline
\end{tabular}




\begin{tabular}{|c|c|c|c|c|c|}
\hline & & & & $\begin{array}{l}<0 \text { : the value must be } \\
\geqslant 0.6\end{array}$ & \\
\hline & 11 & $\begin{array}{l}\text { Energy consumption per unit of } \\
\text { industrial added value }\end{array}$ & $\begin{array}{l}\text { Metric ton } \\
\text { of standard } \\
\text { coal/104 } \\
\text { RMB }\end{array}$ & $\leq 0.5$ & \multirow{2}{*}{$\begin{array}{l}\text { At least } \\
\text { one } \\
\text { indicator } \\
\text { shall reach } \\
\text { the } \\
\text { standard }\end{array}$} \\
\hline & 12 & $\begin{array}{l}\text { Application ratio of } \\
\text { Renewable energy }\end{array}$ & $\%$ & $\geq 9$ & \\
\hline & 13 & $\begin{array}{l}\text { Elastic coefficient of fresh } \\
\text { water consumption }\end{array}$ & - & $\begin{array}{l}\text {-When annual growth } \\
\text { rate of industrial added } \\
\text { value in the EIP } \\
\text { demonstration period } \\
\text { is }>0 \text { : } \leq 0.55 \text {; } \\
\text {-When annual growth } \\
\text { rate of industrial added } \\
\text { value in the EIP } \\
\text { demonstration period is } \\
<0: \geq 0.55\end{array}$ & required \\
\hline & 14 & $\begin{array}{l}\text { Fresh water consumption per } \\
\text { unit industrial added value }\end{array}$ & $\begin{array}{l}\mathrm{m}^{3} / 10^{4} \mathrm{RM} \\
\mathrm{B}\end{array}$ & $\leq 8$ & \multirow{3}{*}{$\begin{array}{l}\text { At least } \\
\text { one } \\
\text { indicator } \\
\text { shall reach } \\
\text { the } \\
\text { standard }\end{array}$} \\
\hline & 15 & $\begin{array}{l}\text { Recycling rate of industrial } \\
\text { water }\end{array}$ & $\%$ & $\geq 75$ & \\
\hline & 16 & Reuse rate of reclaimed water & $\%$ & $\begin{array}{l}\text {-Water deficient } \\
\text { cities }>20 \% \text {; } \\
\text {-Jing-Jin-Ji }{ }^{5} \\
\text { areas }>30 \% \text {; } \\
\text {-Other areas }>10 \%\end{array}$ & \\
\hline \multirow[t]{5}{*}{$\begin{array}{l}\text { Environmental } \\
\text { protection }\end{array}$} & 17 & $\begin{array}{l}\text { Rate of reaching the } \\
\text { discharging standard for key } \\
\text { pollution sources }\end{array}$ & $\%$ & Meet the standard & required \\
\hline & 18 & $\begin{array}{l}\text { The conditions of } \\
\text { national and local key } \\
\text { pollutant emissions }\end{array}$ & - & Meet the standard & required \\
\hline & 19 & $\begin{array}{l}\text { Frequency of severe } \\
\text { environmental accidents }\end{array}$ & - & 0 & required \\
\hline & 20 & $\begin{array}{l}\text { Completion degree of } \\
\text { Environmental management } \\
\text { strategies }\end{array}$ & $\%$ & 100 & required \\
\hline & 21 & Implementation rate of key & $\%$ & 100 & required \\
\hline
\end{tabular}

\footnotetext{
${ }^{5}$ Beijing-tianjin-hebei
} 


\begin{tabular}{|c|c|c|c|c|c|}
\hline & & $\begin{array}{l}\text { enterprises' Clean production } \\
\text { audit }\end{array}$ & & & \\
\hline & 22 & $\begin{array}{l}\text { Centralized sewage treatment } \\
\text { facilities }\end{array}$ & - & exist & required \\
\hline & 23 & $\begin{array}{l}\text { The completion rate of } \\
\text { environmental risk prevention } \\
\text { and control system }\end{array}$ & $\%$ & 100 & required \\
\hline & 24 & $\begin{array}{l}\text { Utilization rate of industrial } \\
\text { solid waste(including hazardous } \\
\text { wastes) }\end{array}$ & $\%$ & 100 & required \\
\hline & 25 & $\begin{array}{l}\text { Elastic coefficient of main } \\
\text { pollutant emissions }\end{array}$ & - & $\begin{array}{l}\text {-When annual growth } \\
\text { rate of industrial added } \\
\text { value in the EIP } \\
\text { demonstration period } \\
\text { is }>0 \text { : the value must be } \\
\leq 0.3 \text {; } \\
\text {-When annual growth } \\
\text { rate of industrial added } \\
\text { value in the } \\
\text { construction period is } \\
<0 \text { : the value must be } \\
\geq 0.3\end{array}$ & required \\
\hline \multirow{7}{*}{$\begin{array}{l}\text { Information } \\
\text { disclosure }\end{array}$} & 26 & $\begin{array}{l}\text { The annual reduction rate of } \\
\text { carbon dioxide emissions per } \\
\text { unit industrial added value }\end{array}$ & $\%$ & $\geq 3$ & required \\
\hline & 27 & $\begin{array}{l}\text { Waste water emission per unit } \\
\text { industrial added value }\end{array}$ & $\mathrm{T} / 10^{4} \mathrm{RMB}$ & $\leq 7$ & \multirow{2}{*}{$\begin{array}{l}\text { At least } \\
\text { one } \\
\text { indicator } \\
\text { shall reach } \\
\text { the } \\
\text { standard }\end{array}$} \\
\hline & 28 & $\begin{array}{l}\text { Solid waste discharge per unit } \\
\text { industrial added value }\end{array}$ & $\mathrm{T} / 10^{4} \mathrm{RMB}$ & $\leq 0.1$ & \\
\hline & 29 & Green cover percentage & $\%$ & $\geq 15$ & required \\
\hline & 30 & $\begin{array}{l}\text { Environmental information } \\
\text { disclosure rate of key } \\
\text { enterprises }\end{array}$ & $\%$ & 100 & required \\
\hline & 31 & $\begin{array}{l}\text { The completion degree of the } \\
\text { ecological industry information } \\
\text { platform }\end{array}$ & $\%$ & 100 & required \\
\hline & 32 & $\begin{array}{l}\text { Times of Eco-industry } \\
\text { Propaganda }\end{array}$ & $\begin{array}{l}\text { Times/Yea } \\
\mathbf{r}\end{array}$ & $\geq 2$ & required \\
\hline
\end{tabular}


The standard for National Eco-industrial Parks (HJ/T274-2015) offers some

2 detail of the calculation and explanations for each indicator. The calculation methods

3 for some of the key indicators are illustrated in Table 3.

Table 3 Calculation method for some new indicators

\begin{tabular}{|c|c|c|}
\hline $\begin{array}{l}\text { No. } \\
\text { (No. in } \\
\text { Table 2) }\end{array}$ & Indicators & Calculation formula \\
\hline $\begin{array}{c}1 \\
(3)\end{array}$ & $\begin{array}{l}\text { The average three-year growth } \\
\text { rate of industrial add value (\%) }\end{array}$ & $\begin{array}{l}\text { [(Industrial added value of the year }\left(10^{4} \mathrm{RMB}\right) / \text { Industrial } \\
\left.\text { added value before three years }\left(10^{4} \mathrm{RMB}\right)^{1 / 3}-1\right] \times 100 \%\end{array}$ \\
\hline $\begin{array}{l}2 \\
(4)\end{array}$ & $\begin{array}{l}\text { The proportion of } \\
\text { remanufacturing industry output } \\
\text { value of the gross industrial } \\
\text { output value }(\%)\end{array}$ & $\begin{array}{c}=\text { output value from remanufacturing industry }\left(10^{4} \mathrm{RMB}\right) / \text { gross } \\
\text { industrial output value }\left(10^{4} \mathrm{RMB}\right) \times 100 \%\end{array}$ \\
\hline $\begin{array}{l}3 \\
(6)\end{array}$ & $\begin{array}{l}\text { Comprehensive utilization rate of } \\
\text { industrial solid waste }(\%)\end{array}$ & $\begin{array}{c}\text { Comprehensive utilization amount }{ }^{6} \text { of industrial solid } \\
\text { wastes }(\mathrm{t}) /[\text { Total production amount of industrial solid } \\
\text { wastes }(\mathrm{t})+\text { storage amount of industrial solid wastes in previous } \\
\text { years }(\mathrm{t})] \times 100 \%\end{array}$ \\
\hline (10) & $\begin{array}{l}\text { Elastic coefficient of } \\
\text { comprehensive energy } \\
\text { consumption }\end{array}$ & $\begin{array}{l}\text { Annual growth rate of comprehensive energy consumption/ } \\
\text { annual growth rate of industrial added value in the EIP } \\
\text { demonstration period }\end{array}$ \\
\hline $\begin{array}{c}4 \\
(21)\end{array}$ & $\begin{array}{l}\text { Implementation rate of key } \\
\text { enterprises' clean production } \\
\text { audit }(\%)\end{array}$ & $\begin{array}{c}\text { number of key enterprises adopting clean production audit } \\
\text { numbers/number of key enterprises } \times 100 \%\end{array}$ \\
\hline $\begin{array}{c}5 \\
(25)\end{array}$ & $\begin{array}{l}\text { Elastic coefficient of main } \\
\text { pollutant emissions }\end{array}$ & $\begin{array}{l}\text { The average annual growth rate of key pollutant emissions } \\
\text { during EIP construction period }(\%) / \text { The average annual growth } \\
\text { rate of industrial added value } \\
\text { In which, The average annual growth rate of key pollutant } \\
\text { emissions=[( emission amount of pollutant in EIP certified } \\
\text { year(metric ton)/ emission amount of pollutant in baseline year } \\
\text { (metric ton }))^{1 / \text { acceptance year - base year }} \\
-1] \times 100 \%\end{array}$ \\
\hline
\end{tabular}

\section{$5 \quad 3.2$ Enforcement of EIP standard}

The management of EIP in China includes the process of application for EIP

7 development, construction, EIP approval and certification, and follow-up examination

8 (MEP, 2015). An EIP working group in the administrative office of the national

\footnotetext{
${ }^{6}$ Comprehensive utilization amount is defined as the total amount of solid waste reused in the industrial park in each year, including the solid waste produced within the industrial park, input from the outside of the industrial park, and stored industrial solid wastes produced in previous years.
} 
1 demonstrative EIP program is in charge of the EIP management, formed by officials

2 from MEP and the Ministry of Commerce and Ministry of Science and Technology.

3 The steps in the process are as follows:

4 (1) Industrial parks that are eager to be certified as EIPs need to first submit their 5 development plan to the EIP administrative office. According to the current practices, 6 the first planning stage tends to last for two or three years for those parks that have 7 already conducted some eco-industrial development practices and obtained an ISO 8 14001-certified environmental management system for the EIP.

(2) Once the EIP development plan has been approved by the administrative office, intensive industrial symbiosis transformation needs to be conducted according to the EIP developing plan. Within 5 years after submission of the EIP development plan, industrial parks under EIP construction are allowed to apply for EIP approval. After inspection by the EIP administrative office, only those industrial parks with all the EIP standards qualified can finally be certified as EIPs (MEP, 2015).

(3) Both industrial parks under construction and certified need to hand over an annual performance evaluation report to the EIP administrative office, reporting their status against of each EIP standard criteria based on self-reported data. Furthermore, afterwards examination will be taken by the EIP administrative office. Three years after certification, part of the EIPs will be randomly selected for follow-up examination. Industrial parks found to be in breach of the standard will have their EIP certification revoked (MEP, 2016). The multistage, progressive EIP accreditation procedure is practically designed to deter the industrial parks that are mostly interested in promoting their public images, but lack genuine environmental commitment to actually implementing EIP development plans (Shi et al., 2012).

It is worth noting that the EIP program in China is entirely voluntary. Each industrial park interested in being recognized as an EIP had to take its own initiative in creating an EIP development plan and submitting its application to SEPA (Shi et al., 28 2012). In the past, MEP did not have tailored policy targeting EIP development, such as financial subsidy. In the latest EIP management plan however (MEP, 2015), the local government and bureau of environmental protection is required to set special funding or give tax preference for industrial parks under EIP construction or approved. 


\section{3 . Analysis of EIP standard modification}

2 3.1 Main changes and improvements of the standard system

3

As introduced, China's EIP standard systems have experienced several rounds of modification since first issued in 2006. In order to explore the changes, the previous standards including HJ/T273-2006, HJ/T274-2006, HJ/T275-2006, HJ/T274-2009 and HJ/T274-2012 are provided in our supplementary material. After a careful comparison of the indicators, the main changes of the series of standard systems are identified as follows.

Comparing HJ/T274-2009 with the Tentative Standard for sector-integrated EIP (HJ/T 274-2006), five indicators including “industrial added value per land unit” , “reuse rate for reclaimed water” , “elastic coefficient of energy consumption” , “elastic coefficient of fresh water", and "implementation rate of cleaner production in key enterprises" are added. Furthermore, threshold values of the centralized sewage processing rate are increased from $\geqslant 70 \%$ to $85 \%$ since $70 \%$ is no longer considered outstanding performance among industrial parks, according to the site investigations of indicator designers. Other indicators are amended to better evaluate EIPs.

In the modification of EIP standard HJ/T274-2009 conducted in 2012, indicators "per-capital industrial added value" and "reuse rate for reclaimed water" were deleted (MEP, 2012; Tian et al., 2012; Fu, 2014). The compiler of the standard from the China Environmental Science Research Institute specifies that the indicator "reuse rate for reclaimed water" was deleted since the water resource in the southern China is relatively sufficient, which reduces incentives for use of reclaimed water for the industrial parks located there. The indicator "per-capital industrial added value" is just moved from the indicator system to fundamental conditions ${ }^{7}$ to apply for EIPs.

\footnotetext{
${ }^{7}$ According to EIP standard HJ/T274-2009, industrial parks aim to apply for EIPs have to meet some fundamental conditions, including (1) pass the certification of ISO 14000. (2) average growth rate of the industrial added value in the recent 3 years is no less than the average local level for industrial parks. (3) environmental pollution from each enterprise can meet the national and local standard, and there is no occurrence of serious environmental accident happened in the recent 3 years.
} 
The EIP standard HJ/T274-2015 experienced a substantial change comparing

2 with the previous versions. In the following we will discuss the key improvements and the underlying reasons for the modification into HJ/T274-2015 .

(1) "Three in one" EIP standard

In comparison with the previous versions, the primary change in the new Standard for National Eco-industrial Parks is that the latest amendment (HJ/T274-2015) removed the classification of EIPs into three categories with specific indicator for each. The "three in one" system helps to avoid the confusion in the classification of EIP as in some instances sector-integrated EIP (with a primary industrial sector) could be also classified as sector-specific EIP (Zhu et al., 2014; Yan, 11 2015).

Furthermore, the scope of the standard is more comprehensive in the new version. 13 The standards of sector-integrated EIP (HJ/T274-2009), sector-specific EIP (HJ/T273-2006) and venous EIP (HJ/T275-2006) contained four categories of indicators: 1) economic development, 2) material reduction and recycling, 3) pollution control, and 4) administrative and management indicators, with 26, 19 and 20 indicators respectively. The Standard for National Eco-industrial Parks (HJ/T274-2015) comprises five categories of indicators: 1) economic development, 2) industrial symbiosis, 3) resource conservation, 4) environmental protection and 5) information disclosure, with 32 indicators in total. In parallel, the threshold values of several indicators become more stringent since the previous thresholds no longer represent outstanding environmental performance relative to other industrial parks. For instance, requirement of fresh water consumption per unit industrial added value changed from $\leqslant 9 \mathrm{~m}^{3} /$ ten thousand $\mathrm{RMB}$ to $\leqslant 8 \mathrm{~m}^{3} /$ ten thousand RMB. The minimal requirement of Waste water emission per unit industrial added value is modified from $\leqslant 8 \mathrm{t} /$ ten thousand RMB to $\leqslant 7 \mathrm{t} /$ ten thousand RMB.

(2) Supplement industrial symbiosis criteria

Industrial symbiosis is defined as encouraging traditionally separate industries to adopt a collective approach building competitive advantage by incorporating physical exchange of materials, energy, water and by-products into their business processes 31 (Chertow, 2000). The essence of industrial symbiosis is the trade of by-products and 32 waste among enterprises such as the case of Kalundborg in Denmark (Shi et al., 2012; 
1 Geng et al., 2016). The previous versions of EIP standard systems did not include any

2 indicator regarding industrial symbiosis. The new standard includes indicators on

3 evaluating the level of materials exchange at EIP level. The added indicator "The

4 added new eco-industrial chain project numbers after enforcing EIP demonstration

5 program" 8 can help to encourage the tenant enterprises to seek the potential network

6 of industrial symbiosis with others, which will facilitate the network establishment of

7 industrial symbiosis. The indicator "Usage rate of renewable resources" included in

8 the new EIP standard (HJ/T274-2015) can help to emphasize the regeneration and

9 reutilization of renewable resources under the network of industrial symbiosis. The

10 addition of industrial symbiosis criteria can undoubtedly encourage and better

11 evaluate the industrial symbiosis actions in industrial parks.

12 (3) Involve environmental risk control indicators

13 The extensive applications of hazardous materials such as ammonia together 14 with deficient management have caused several risk accidents. The fire and explosion accident happened in August, 2015 in Tianjin Binhai New Area was found to have been caused by irregular management of hazardous materials ${ }^{9}$. Reviewing of the previous three versions of standards found that there was no indicator regarding the control or manage of these hazardous materials or environmental risk accidents. Given this circumstance, the supplement indicator such as "The completion rate of environmental risk prevention and control system" and "Frequency of severe environmental accidents in enterprises" in the new EIP standard (HJ/T274-2015) aims to prevent and control the environmental risk issue to a certain extent.

(4) Include more environmental indicators

The new EIP standard (HJ/T274-2015) set more comprehensive environmental indicators by setting indicator "Elasticity coefficient of main pollutant emissions", targeting relative decoupling of resource consumption and pollutants emission along with economic growth. Here the key pollutants refer those under national overall 28 volume control--COD, $\mathrm{SO}_{2}, \mathrm{NH}_{3}$, etc. Under the circumstance that the air pollution is 29 still serious in China, the added environmental indicators can help better monitoring

\footnotetext{
8 i.e. the number of new connections between firms and/or facilitaties operating in the EIP, in terms of exchanges of energy and materials.

${ }^{9}$ More information of the Tianjin Binhai New Area accident in 2015 can be found in http://news.sohu.com/s2015/tjbaozha/
} 
1 the environmental pollution and encouraging pollution control in the EIP. Meanwhile,

2 with the supplementary indicator "The annual reduction rate of carbon dioxide

3 emissions per unit industrial added value", $\mathrm{CO}_{2}$ emission reduction is also evaluated

4 in the new EIP standard. Feedback from China Environmental Science Research

5 Institute declares that the supplement $\mathrm{CO}_{2}$ indicator is a positive response to China's

6 commitment to peak GHG emissions before 2030.

$7 \quad$ (5) Provide optional indicators

8 The previous EIP standard system is made up by a system of compulsory 9 indicators. In the current modified standard, optional indicators have also been 10 included. Feedback from the drafting committee of HJ/T274-2009--China 11 Environmental Science Research Institute indicated that the offering of optional 12 indicators can involve more industrial parks with different development 13 characteristics. Among the total 32 indicators, 17 are obligatory ones and 15 are 14 optional ones. At least 23 indicators need to reach the standard for the industrial park 15 to pass the EIP evaluation. For instance, in the category of economic development, 16 only one indicator is required to be met among the four indicators. Industrial symbiosis, resource conservation and environmental protection also include optional indicators, leaving the category "information disclosure" with only obligatory 19 indicators.

(6) Give flexibility in the indicator targets

In order to provide more flexibility and ensure more consistent evaluation, the new EIP standard system (HJ/T274-2015) gives some flexibility in setting the targets for a number of indicators based on different contextual conditions. Among the 32 indicators, three elasticity coefficient indicators (elastic coefficient of energy consumption, elastic coefficient of fresh water consumption and elastic coefficient of main pollutant emissions) and reuse rate of reclaimed water give distinct indicator criteria depending on the economic circumstances of the park. For instance, in the previous standard for sector-integrated EIP (HJ/T274-2009), the energy consumption elasticity coefficient is required to meet the target " $<0.6$ ". In HJ/T274-2015, the criterion is adjusted taking into account the annual growth rate of industrial added

31 value in the EIP demonstration period. The new standard system requires that when 32 the growth rate of added value is $>0$, then the corresponding standard is $\leq 0.6$; if the 
1 annual growth rate of industrial added value in the EIP demonstration period is $<0$,

2 then the corresponding standard is $\geq 0.6$ ". In other instances, targets are established

3 taking into account of regional characteristics.

$4 \quad 3.2$ Shortcomings and Outlook of the EIP standard development

Although many positive changes and improvement have been identified, there are still some shortcomings exist in the new EIP standard. Based on the feedback from compilers of the standard in the China Environmental Science Research Institute,

8 EIP administrative office and academic resarchers in the EIP fields, the potential improvement for promoting the EIP standard is discussed in the following:

(1) Further improve the industrial symbiosis indicators

It is a significant improvement since the new EIP standard (HJ/T274-2015) has absorbed three indicators to evaluate industrial symbiosis actions in EIP. However, our respondents comment that the indicator "number of symbiotic linkages established after the park's EIP development has been approved by the EIP administrative office formally" can only reflect the eco-industrial chain numbers without assessing the practical benefits resulting from industrial symbiosis. In order to fill this gap, economic contribution resulted from industrial symbiosis should be considered in EIP evaluation. In addition, industrial symbiosis should not be limited to solid waste or renewable resource as the existing indicators instructed. Energy sharing measures such as waste heat recovery and reuse should also be encouraged and involved in the EIP evaluation.

Furthermore, our respondents suggest industrial symbiosis behaviors outside the industrial park should also be evaluated and encouraged since EIP should ideally make use of opportunities for material or energy exchange with the local community. The review finds that the existing eco-efficiency indicators focus only on the firms and activities within the designated industrial park. It would be desirable to develop new indicators to clarify how designated industrial parks are linked to other areas and how the industrial symbiosis actions in and outside the EIP can promote the local sustainable development. This concept, termed as urban symbiosis, recognizes the use of municipal solid waste as inputs to industries for example (Dong et al., 2014).

(2) Include social benefit evaluation indicators 
The practical implementation of EIP will involve and have implications on

2 environmental, economic and social dimensions. Thus, a systematic evaluation on

3 various aspects should be addressed. Analysis of several existing industrial park cases

4 reveals that no symbiosis or utility sharing can materialize even if physical features

5 are all present but social factors are lacking (Valenzuela-Venegas et al., 2016).

6 However, the published new EIP standard (HJ/T274-2015) does not include any

7 social benefit evaluation indicator. Considering social responsibility is quite important

8 for both enterprises and industrial parks, it is quite necessary to include social benefit

9 evaluation indicators such as "Occupational Health and Safety", "employment rate",

10 "employees' average wage earnings" and "the degree of public awareness and 11 participation" for evaluating EIPs.

12 (3) Strengthen the reduction action evaluation

13 The 3Rs (Reduce, Reuse and Recycle) are a core principle for circular economy, 14 also is the key rule guiding EIP construction ( $\mathrm{Su}$ et al., 2013). Among the 3Rs, 15 reduction namely prevention is the most important objective (Akenji et al. 2016). 16 Indicators reviewing the new EIP standard (HJ/T274-2015) found that only energy 17 and water consumption burden per industrial added value are 18 considered--“Comprehensive energy consumption per unit industrial added value" 19 and "Fresh water consumption per unit industrial added value". The lack of any 20 broader reduction evaluation indicator could become an incentive for enterprises 21 preferring recycling and reuse based solutions over the more preferable prevention 22 and source reduction solutions integrated into the design of products and in 23 production process. Thus, it is quite urgent to involve reduction monitoring and 24 evaluation indicators for assessing EIPs. A key would be to start monitoring materials 25 more systematically, in line with e.g the 2008 OECD manual on measuring material 26 flows and resource productivity, and to strengthen efforts to boost markets for 27 secondary resources.

28 (4) Provide incentives for promoting EIPs

29 Within the current Chinese EIP management system, there is no economic 30 incentive policy for EIPs. Based on the feedback from our respondents, several 31 incentive approaches are feasible to motivate industrial parks. For instance land 32 preference policy, tax discount for EIPs and involved enterprises, and administrative 33 support for EIP enterprises. Some local environmental protection agencies are also 
1 trying to establish specific foundation for supporting eco innovation movement.

2 Top-down incentive policies and local attempts are both desirable for promoting EIPs

3 development in China.

4

\section{4. Concluding Remarks}

China is the only country establishing and practicing national EIP standard and

7 indicators (Cote and Liu, 2016). Reflection on the experience indicates that

8 development of practical quantitative assessment indicators for EIPs has been a

9 crucial factor for the ongoing success of China's national demonstration EIP program.

10 Up to date, EIP standard in China has already experienced several round of revision

11 since the first rounds of declaration in 2006. In 2015, MEP released the new standard

12 for national demonstration EIP (HJ/T274-2015) to replace the previous standards of

13 sector-integrated EIP, sector-specific EIP and the venous industry EIP.

14 This study gives a review of China's EIP standard systems, and undertakes an analysis of the new released EIP standard. Comparing with indicators of previous three standard systems, the newly released EIP standard (HJ/T274-2015) has obvious improvements. Most of the previous shortcomings (e.g. vague and intricate indicators, and lack of industrial symbiosis indicators) discussed by scholars like Geng (2008; 2009; 2012) have been modified to some extent. Besides these improvements, environmental risk control indicators and more comprehensive environmental indicators are also amended in the new EIP standard (HJ/T274-2015), as environmental pollution and effective risk prevention and control remain as significant challenge in China.

Through the review and analysis of China's EIP standard, the circumstance of 25 how China is conducting EIP management with guiding criteria is clearly shown. 26 With accurate and programmatic indicators, EIP development can be better promoted 27 along with efficient monitoring and evaluation. For the years ahead we propose the 28 inclusion of more material-oriented indicators to unleash the potential of resource 29 efficiency and boost markets for secondary resources. Such shift is likely to be in line 30 with a more saturating Chinese economy whose demand for primary materials is 
1 likely to flatten (Bleischwitz et al, forthcoming) as well as with broader attempts in such direction in both Europe and China (McDowall et al. 2017).

China's experience of setting EIP standards and indicators may provide lessons for other countries' attempt to develop industrial estate indicators and designate such parks towards eco-innovation strategies. In order to observe and effectively promote EIP more widely at an international and global scale, there are some remaining research questions that need further exploration, for instance, how will the existing EIP indicators and the proposed flexibility actually be applied across parks, and what lessons can be learned? What are the lessons for designing any national EIP standards in either more top-down EIP mode countries e.g. US, Canada and Asia, or more bottom-up EIP mode countries e.g. European countries (Ghisellini, 2016)? What may speak in favour of an international EIP standard, and what would be core indicators? What are broader lessons for eco-innovation performance of industries and countries? After all this article should allow scholars to learn about recent progress in Chinese EIP programand we believe the EIP development at the global range can

\section{Acknowledgements}

The research work of this paper was supported by a grant from the National Natural Science Foundation of China (No.71403170, No.71325006, No. 71461137008) as well as through a grant from UK ESRC (ES/L015838/1). Many thanks for the feedback from Dr. Minghui Xie from China Environmental Science Research Institute. We also appreciate the comments from the editor and three anonymous reviewers.

\section{References}

Akenji, L., Bengtsson, M., Bleischwitz, R., Tukker, A., Schandl, H. (2016): Ossified materialism: introduction to the special volume on absolute reductions in materials throughput and emissions, J. Cleaner Prod .132: 1-12.

Bai, L., Qiao, Q., Yao, Y., Guo, J., Xie, M.H., 2014. Insights on the development progress of National Demonstration eco-industrial parks in China. J. Cleaner Prod.70, 4-14.

Bleischwitz, R. (Ed.) (2007): Corporate Governance of Sustainability: A Co-Evolutionary View on Resource Management. Edward Elgar Publisher.

Boons, F., Chertow, M., Park, J., Spekkink, W., Shi, H. 2017. Industrial symbiosis dynamics and the problem of equivalence. J. Ind. Ecol. 21, 4: 938-952. 
1 Chertow, M.R., 2000. Industrial symbiosis: literature and taxonomy. Annu. Rev. Energy Env. 25,313-337.

Chiu, A.S.F., 2001. Ecology, System, and Networking: Walking the Talk in Asia. J. Ind. Ecol. $5(2), 6-8$.

Cote, R.P., Cohen-Rosenthal, E. 1998. Designing eco-industrial parks: a synthesis of some experiences. J. Cleaner Prod. 6 (3-4), 181-188.

Cote, R.P., and Liu, Z., 2016. Eco-industrial Park Performance Standards and Indicators and the Circular Economy Report. Devens, Massachusetts USA.

Cui, D.S., Zeng, Q.L. Cui, Discussion on efficiency evaluation index system of integrated eco-industrial park. Journal of Hunan Agricultural University. 2016.17 (1):94-99.(in Chinese)

Dong, H.J., Ohnishi, S. , Fujita, T., Geng, Y., Fujii, M., Dong, L., 2014. Achieving carbon emission reduction through industrial \& urban symbiosis: A case of Kawasaki. Energy 64, 277-286.

Ehrenfeld, J. and Gertler, N., 1997. Industrial Ecology in Practice: The Evolution of Interdependence at Kalundborg. J. Ind. Ecol. 1(1), 67-79.

MEP , Administration Measure for National Demonstration Eco-industrial Parks (Compilated Instruction). http://www.mep.gov.cn/gkml/zj/wj/200910/t20091022_172490.htm.

Fang, Y.P., Cote, R.P., and Qin, R., 2007. Industrial sustainability in China: Practice and prospects for eco-industrial development. J. Environ. Manage. 83(3), 315-328.

Fleig, A.K., 2000. Eco-industrial parks: A strategy towards industrial ecology in developing and newly industrialised countries. Deutsche Gesellschaft für Technische Zusammenarbeit (GTZ), Federal Republic of Germany.

Fu, L.N., 2014. Research on Ecological Transformation of Industrial Park and its Eco-efficiency. Hunan, Central South University.

Geng, Y. and Cote, R., 2003. Environmental management system at industrial park level in China. J. Environ. Manage. 31(6), 784-794.

Geng, Y., Zhang, P., Cote, R., Qi, Y., 2008. Evaluating the applicability of the Chinese eco-industrial park standard in two industrial zones. Int. J. Sust. Dev. World. 15(6), 543-552.

Geng, Y., Zhang, P., Cote, R., Fujita, T., 2009. Assessment of the national eco-industrial park standard for promoting industrial symbiosis in China. J. Ind. Ecol. 13(1), 15-26.

Geng, Y., Fujita, T., Chen, X.D., 2010. Evaluation of innovative municipal solid waste management through urban symbiosis: a case study of Kawasaki. J. Cleaner Prod.18, 993-1000.

Geng, Y., Fu, J., Sarkis, J. and Xue, B., 2012. Towards a national circular economy indicator system in China: an evaluation and critical analysis. J. Cleaner Prod. 23, 216-224.

Geng, Y., Sarkis, J., Ultiati, S., Zhang, P. 2013. Measuring China's circular economy. Science 339, 37 1526-1527. 
Geng, Y, Sarkis, J. and Ulgiati, S., 2016. Sustainability, well-being, and the circular economy in China and worldwide 6278(supplement), 73-76.

Ghisellini, P., Cialani, C., Ulgiati, S., 2016. A review on circular economy: the expected transition to a balanced interplay of environmental and economic systems. J. Cleaner Prod. 114:11-32

Kim, D. and Powell, J.C., 2008. Comparison of Eco-Industrial Development between the UK and Korea. EU-Korea Conference on Science and Technology 124,443-454.

Lai, B.J.,2013. Research on environmental performance index of eco-industrial park development in China. Beijing, Tsinghua University.

Liu, J.Y., Qiao, Q., Yao, Y., Guo Y.W. 2007. A study on evaluation index system of eco-industrial parks: Sector-integrated eco-industrial parks. Modern Chemical Industry. 7.58-61 (in Chinese)

Lowe, E., 1997. Creating by-product resource exchanges: strategies for eco-industrial parks. J. Cleaner Prod. 5, 57-65.

Massard,G., Jacquat, O., Zurcher, D. 2014. International survey on eco-innovation parks. Learning from experiences on the spatial dimensions of eco-innovation. Federal office for the environment and the ERA-NET ECO-INNOVERA. Bern. Environmental studies no.1402.

Mathews, J., Tan, H. (2016): Lessons from China, in: Nature (Special issue on the circular economy).531: $440-442$.

McDowall, W., Geng, Y., Huang, B.J., Bartekova, E., Bleischwitz, R., Turkeli, S., Kemp,R., Domenech, T. Circular Economy Policies in China and Europe. J. Ind. Ecol. 2017.21.3: 651-661.

Ministry of Environmental Protection (MEP) of the People's Republic of China, 2009. HJ/T274-2009. http://www.zhb.gov.cn/gkml/hbb/bgg/201208/t20120809 234561.htm. Access on 2016.10 .20

Ministry of Environmental Protection (MEP) of the People's Republic of China, 2015. HJ/T274-2015. http://bz.mep.gov.cn/bzwb/other/qt/201512/t20151224_320149.htm. Access on 2016.10 .20

Ministry of Environmental Protection (MEP) of the People's Republic of China, Management of follow-up examination of EIP.2016 http://www.mep.gov.cn/gkml/hbb/bgth/201602/t20160215 330241.htm. Access on 2016.10.20

Park, J.M., Park, J.Y., Park,H.S.,2016. A review of the national eco-industrial park development program in Korea: progress and achievements in the first phase, 2005-2010. J. Cleaner 
Tian, J.P., Liu, W., Lai, B.J., Li, X., Chen, L.J. 2014. Study of the performance of eco-industrial park development in China. J. Cleaner Prod.64: 486-494.

Roberts, B.H., 2004. The application of industrial ecology principles and planning guidelines for the development of eco-industrial parks: an Australian case study. J. Cleaner Prod.12 (8-10), 997-1010.

Shi, L., Liu, G.G. and Guo, S.P. 2012. International comparison and policy recommendation on the development model of industrial symbiosis in China. Acta Ecologica Sinica 32(12), 3950-3957.

Shi H., Tian J.P. and Chen L.J. 2012.China's quest for Eco-industrial Parks, Part I. J. Ind. Ecol.16(5):8-10

Song, X.Y., Shen, J., 2015. The ecological performance of eco-industrial parks in Shandong based on principal component analysis and set pair analysis. Resource Science 37(3), 0546-0554.

Su, B.W., Heshmati, A., Geng, Y. and Yu, X.M., 2013. A review of the circular economy in China: moving from rhetoric to implementation. J. Cleaner Prod. 42, 215-227.

Tian, J.P., Liu, W., Li, X., Lai, B.J. and Chen, L.J., 2012.Study of Eco-industrial Park Development Mode in China. China Population, Resources and Environment, 22(7), 60-66.

United Nations Environmental Programme (UNEP), 1997. The environmental management of industrial estates. UNEP Industry and Environment, Paris, France.

Valenzuela-Venegas G., Salgado J.C, Díaz-Alvarado F.A.,2016. Sustainability indicators for the assessment of eco-industrial parks: classification and criteria for selection. J. Cleaner Prod. 133 , 99-116.

Van Beers, D., Corder, G., Bossilkov, A., and Van Berkel, R., 2007. Industrial symbiosis in the Australian minerals industry: The cases of Kwinana and Gladstone. J. Ind. Ecol. 11(1), $55-72$.

Van Berkel, R., Fujita, T., Hashimoto, S. and Geng, Y., 2009. Industrial and urban symbiosis in Japan: Analysis of the Eco-Town program 1997-2006. J. Environ. Manage. 90(3), 1544-1556.

Van Berkel, R., 2007.Cleaner production and eco-efficiency initiatives in Western Australia 1996-2004. J. Cleaner Prod. 15(8-9), 741-755.

Yan, M., 2015. Research on the Index System of Regulatory Detailed Planning of Cheng De Industrial Park According to the Industrial Characteristics. Sichuan, Southwest University of Science and Technology.

Yu, C. Dijkema, G.P.J., de Jong. M. 2014. What makes eco-transformation of industrial parks take off in China? J. Ind. Ecol.19 (1):441-456.

Yu, F., 2015. Patterns, driving factors and environmental benefits evaluation of industrial symbiosis in industrial parks. Shandong, Shandong University.

Zhang, L., Yuan, Z.W. and Bi, J., 2010. Eco-industrial parks: national pilot practices in China. J. Cleaner Prod. 18,504-509. 
1 Zhong, Q.D., Yao, Y., Qiao, Q., Bai, W.N. and Fang, L., 2014. Development progress and 2 regional characteristics of eco-industrial parks in China. Journal of Environmental Engineering 3 Technology $4(5), 429-435$.

4 Zhu, Q.H., Cote, P., 2004. Integrating green supply chain management into an embryonic 5 eco-industrial development: a case study of the Guitang Group. J. Cleaner Prod. 12(8-10), $6 \quad 1025-1035$.

7 Zhu, Q.H., Lowe, E., Wei, Y, Barnes, D., 2007. Industrial symbiosis in China: a case study of the 8 Guitang Group. J. Ind. Ecol. 11(1), 31-42.

9 Zhu, Q.H., Geng, Y., Sarkis, J. and Lai, K.H., 2014. Barriers to Promoting Eco-Industrial Parks 10 Development in China. J. Ind. Ecol. 19(3), 457-467. 